Original Research Paper

\title{
Analisis Kemampuan Berpikir Kritis Siswa Pokok Bahasan Klasifikasi Materi dan Perubahannya
}

\author{
Shofwan Ridho ${ }^{1 *}$, Ruwiyatun ${ }^{1}$, Bambang Subali ${ }^{1}$, Putut Marwoto ${ }^{1}$ \\ ${ }^{1}$ Program Pascasarjana Universitas Negeri Semarang, Indonesia;
}

DOI: 10.29303/jppipa.v6i1.194

Citation: Ridho, S., Ruwiyatun, Subali, B., Marwoto, P. 2020. Analisis Kemampuan Berpikir Kritis Siswa Pokok Bahasan Klasifikasi Materi dan Perubahannya. Jurnal Penelitian Pendidikan IPA (JPPIPA). 6(1). pp. 10-15.

\section{Article history}

Received: December $6^{\text {th }} 2019$

Revised: September $25^{\text {th }} 2019$

Accepted: October $14^{\text {th }} 2019$

*Shofwan Ridho: Program

Pascasarjana Universitas Negeri

Semarang, Indonesia;

Email: ridho.spextrum@gmail.com

\begin{abstract}
This study aims to analyze students' critical thinking skills in science education on the subject matter of classification of material and its changes. This study included quantitative descriptive research. The subjects of this study were the eighth-grade students of MTs Wahid Hasyim Warungasem, Batang with a total of 27 students. The technique of collecting data uses the questions of critical thinking skills which number ten questions. The results showed that critical thinking skills in the basic explanatory aspects were $31 \%$ (low category), building basic skills by $61 \%$ (medium category), concluded by $17 \%$ (very low category), making further explanations of $46 \%$ (medium category), and strategy and technique of $20 \%$ (very low). Thus, the average critical thinking ability of students as a whole is in the low category with an achievement percentage of $35.2 \%$.
\end{abstract}

Key Words: Analysis of Critical Thinking; Science Education; Material Classification.

\begin{abstract}
Abstrak: Penelitian ini bertujuan untuk menganalisis kemampuan berpikir kritis siswa dalam pelajaran Ilmu Pengetahuan Alam (IPA) pada pokok bahasan klasifikasi materi dan perubahannya. Penelitian ini termasuk penelitian deskriptif kuantitatif. Subjek penelitian ini adalah siswa kelas VIII MTs Wahid Hasyim Warungasem, Batang sejumlah 27 siswa. Teknik pengumpulan data menggunakan soal keterampilan berpikir kritis yang berjumlah sepuluh butir soal. Hasil penelitian menunjukkan bahwa kemampuan berpikir kritis pada aspek penjelasan dasar sebesar 31\% (kategori rendah), membangun keterampilan dasar sebesar $61 \%$ (kategori sedang), menyimpulkan sebesar 17\% (kategori sangat rendah), membuat penjelasan lebih lanjut sebesar $46 \%$ (Kategori sedang), serta strategi dan teknik sebesar $20 \%$ (sangat rendah). Dengan demikian rata-rata kemampuan berpikir kritis siswa secara keseluruhan berada pada kategori rendah dengan persentase pencapaian sebesar $35.2 \%$.
\end{abstract}

Kata Kunci: Analisis Berpikir Kritis; Pendidikan IPA; Klasifikasi Materi dan Perubahannya

\section{Pendahuluan}

Mata pelajaran Ilmu Pengetahuan Alam (IPA) di sekolah tingkat pendidikan dasar sesuai dengan Permendikbud nomor 22 Tahun 2006 bertujuan untuk mengembangkan keterampilan proses guna menyelidiki alam sekitar, memecahkan masalah, dan membuat keputusan. Memasuki era abad-21 terjadi perubahan yang sangat besar di berbagai bidang yang sering disebut revolusi industri 4.0. Tujuan pendidikan di era revolusi industri 4.0 diharapkan memperoleh lulusan pendidikan yang kompeten dalam hal memanfaatkan ICT (Information and Communication Technologies) tetapi juga kompeten dalam kemampuan 
literasi, berpikir kritis, memecahkan masalah, komunikasi, kolaborasi, dan memiliki kualitas karakter yang baik (Syamsuar dkk, 2018). Kemampuan abad ke-21 yang dibutuhkan di dunia usaha dan dunia industri adalah keterampilan teknologi dan media informasi, kehidupan dan karir, keterampilan dan belajar berinovasi yang didalamnya meliputi berpikir kritis dan mengatasi masalah (Wijaya, Sudjimat, \& Nyoto, 2016). Penerapan K-13 agar optimal untuk menjawab tantangan abad-21 diperlukan pemahaman lebih tentang hakikat pembelajaran dan menciptakan situasi akademik yang pembelajarannya mengarahkan pada keterampilan analistis, kritis dan kreatif (Sudarisman, 2015).

Pendekatan pembelajaran di antara generasi alfa dan tantangan dunia pendidikan era revolusi industri 4.0 harus mampu merangsang kemampuan berpikir kritis, sikap kreatif dan juga merangsang siswa untuk bertanya sepanjang hayat (Gazali, 2018). Keterampilan pada abad-21 diorganisasikan kedalam empat kategori yaitu cara untuk bekerja, alat untuk bekerja, cara untuk hidup dan cara berpikir yang salah satunya yaitu keterampilan berpikir kritis (Dicerbo, 2014). Berpikir kritis merupakan berpikir dengan cara rasional dan reflektif sehingga dapat memutuskan tentang apa yang dilakukan atau dipercayainya (Ennis, 2011). Menurut Liberna (2013) menyatakan bahwa kemampuan berpikir kritis merupakan kemampuan memecahkan masalah yang sangat penting bagi setiap orang yang digunakan untuk kehidupan sehari-hari melalui berpikir serius, aktif, teliti dalam menganalisis semua informasi yang diterima dengan menyertakan alasan yang rasional sehingga tindakan yang akan dilakukannya adalah benar. Keyakinan dan kemampuan berpikir kritis saling berkaitan. Ketika keyakinan seseorang akan suatu kebenaran, maka diperlukan kemampuan berpikir kritis. Begitu juga ketika akan mengembangkan kemampuan berpikir kritisnya maka dibutuhkan keyakinan tertentu akan suatu kebenaran (Kleinig, 2018).

Keterampilan berpikir kritis tentunya tidak terlepas dalam mata pelajaran IPA di sekolah. Peran keterampilan berpikir kritis sangat penting dalam pembelajaran IPA yang berguna untuk penerapan sains dalam masyarakat dengan penuh tanggung jawab (Santos, 2017). Pokok bahasan klasifikasi materi dan perubahannya merupakan salah satu materi dalam mata pelajaran IPA. Keterampilan berpikir kritis dapat dilatihkan kepada semua siswa melalui sebuah pembelajaran. Pembelajaran akan mudah dilaksanakan untuk mencapai tujuan yang maksimal apabila sudah diketahui kemampuan awal siswa dalam hal keterampilan berpikir kritisnya. Berdasarkan latar belakang tersebut penelitian ini bertujuan menganalisis keterampilan berpikir siswa pada pokok bahasan klasifikasi materi dan perubahannya.

\section{Metode}

Metode penelitian ini adalah deskriptif dengan pendekatan kuantitatif. Penelitian deskriptif (descriptive research) merupakan penelitian yang memberi gambaran yang lebih jelas, eksplorasi terhadap sesuatu fenomena atau kejadian dengan cara mendeskripsikan sejumlah variabel yang berkenaan dengan masalah dan unit yang diteliti. Teknik analisis data dalam penelitian ini menggunakan pengolahan statistik yang bersifat deskriptif (statistic deskriptif). Teknik pengambilan sampel dalam penelitian ini dalah teknik purposive sampling. Berdasarkan pertimbangan peneliti, kelas VIIIB layak untuk dijadikan subjek penelitian. Subjek penelitian ini adalah siswa kelas VIII MTs Wahid Hasyim Warungasem, Batang sejumlah 27 siswa semester ganjil tahun ajaran 2018/2019.

Peneliti menggunakan instrumen identifikasi kemampuan berpikir kritis siswa berupa soal tes pilihan ganda berjumlah sepuluh butir. Tes yang digunakan pada penelitian ini adalah soal tes pilihan ganda mata pelajaran IPA dengan pokok bahasan klasifikasi materi dan perubahannya yang telah divalidasi oleh pakar. Dalam penyusunan tes berpikir kritis, peneliti berpedoman dengan indikator materi yang digunakan sekolah dan indikator berpikir kritis menurut Enis. Indikator keterampilan berpikir kritis menurut Enis sebagaimana dikutip oleh (Saputra dkk, 2016) meliputi, 1) memberikan penjelasan sederhana, 2) membangun keterampilan dasar, 3) menyimpulkan, 4) memberikan penjelasan lebih lanjut serta 5) strategi dan teknik. Pengelompokan kemampuan berpikir kritis siswa digolongkan dalam lima kategori yaitu kategori sangat rendah, rendah, sedang, tinggi dan sangat tinggi. Persentase penggolongan kemampuan berpikir kritis terdapat pada Tabel 1.

Tabel 1. Kategori Persentase Kemampuan Berpikir Kritis

\begin{tabular}{ll}
\hline Persentase Pencapaian $(\%)$ & Kategori \\
\hline $80<\mathrm{PK} \leq 100$ & Sangat Tinggi \\
$60<\mathrm{PK} \leq 80$ & Tinggi \\
$40<\mathrm{PK} \leq 60$ & Sedang \\
$20<\mathrm{PK} \leq 40$ & Rendah \\
$0<\mathrm{PK} \leq 20$ & Sangat Rendah \\
\hline
\end{tabular}

\section{Hasil dan Pembahasan}

Kemampuan berpikir kritis merupakan proses berpikir melalui analisis, berpikir serius, dan teliti dalam sebuah informasi yang diterima dengan menyertakan alasan yang rasional sehingga akan menghasilkan tindakan yang sesuai. Kemampuan berpikir kritis siswa bisa dilatih secara bertahap. Guru harus berperan memotivasi dan meyakinkan siswa agar selalu melatih kemampuan berpikir kritisnya. Hal 
tersebut bisa berpengaruh karena kemampuan berpikir siswa dipengaruhi oleh kepercayaan diri siswa (Tresnawati dkk, 2017). Perlunya kemampuan berpikir kritis dalam pembelajaran akan berdampak pada siswa untuk menghadapi permasalahan dalam kehidupan sehari-hari. Kemampuan berpikir kritis berguna untuk memeriksa kebenaran suatu informasi, sehingga siswa akan memutuskan sebuah informasi layak diterima atau ditolak (Kalelioglu. dkk, 2013). Pokok bahasan klasifikasi materi dan perubahannya mempunyai kompetensi dasar yang harus dicapai siswa yaitu K.D. 3.3 Menjelaskan konsep campuran dan zat tunggal (unsur dan senyawa), sifat fisika dan kimia, perubahan fisika dan kimia dalam kehidupan sehari hari serta K.D. 4.3 Menyajikan hasil penyelidikan atau karya tentang sifat larutan, perubahan fisika dan perubahan kimia, atau pemisahan campuran.

Kemampuan berpikir kritis yang diukur dalam penelitian ini terdiri dari indikator berpikir kritis yang meliputi, 1) penjelasan sederhana, 2) membangun keterampilan dasar, 3) menyimpulkan, 4) memberikan penjelasan lebih lanjut, 5) strategi dan teknik. Setiap butir soal yang diujikan disesuaikan dengan indikator berpikir kritis dengan pokok bahasan klasifikasi materi dan perubahannya. Setiap soal merupakan bagian yang terpisah antara soal satu dengan soal yang lainnya, sehingga tidak ada soal yang berfungsi sebagai prasyarat untuk menyelesaikan soal selanjutnya. Soal berpikir kritis yang diujikan kepada siswa sebanyak sepuluh butir soal dengan tipe soal pilihan ganda. Penggunaan soal pilihan ganda untuk keterampilan berpikir kritis merupakan bentuk soal yang paling luas penggunaanya, sehingga dapat digunakan guru dengan jumlah peserta didik yang banyak, soal pilihan ganda dapat digunakan sebagai soal yang mempunyai standar karena memiliki tingkat objektivitas dan validitas yang tinggi. Namun, penyusunan butir soal pilihan ganda memerlukan banyak waktu dan sumber referensi, sehingga diperlukan perhatian khusus untuk menyusunnya (Hartini dkk, 2015). Hasil dari uji coba soal kemampuan berpikir kritis tersebut diperoleh data berupa jawaban siswa yang kemudian dianalisis oleh peneliti. Hasil uji coba soal kemampuan berpikir kritis disajikan pada Tabel 2.

Tabel 2. Hasil Kemampuan Berpikir Kritis

\begin{tabular}{lll}
\hline \multirow{2}{*}{ No } & Indikator Berpikir Kritis & $\begin{array}{l}\text { Persentase } \\
\text { Ketercapaian }\end{array}$ \\
\hline 1 & Memberikan penjelasan sederhana & $31 \%$ \\
2 & Membangun keterampilan dasar & $61 \%$ \\
3 & Menyimpulkan & $17 \%$ \\
4 & Memberikan penjelasan lebih lanjut & $46 \%$ \\
5 & Strategi dan teknik & $20 \%$ \\
\hline
\end{tabular}

Tabel 2 menunjukan hasil kemampuan berpikir kritis siswa. Pada indikator 1 memberikan penjelasan dasar memiliki persentase ketercapaian sebesar $31 \%$; indikator 2 membangun keterampilan dasar memiliki persentase ketercapaian sebesar $61 \%$; indikator 3 menyimpulkan memiliki persentase ketercapaian sebesar 17\%; indikator 4 memberikan penjelasan lebih lanjut memiliki persentase sebesar $46 \%$ serta indikator 5 strategi dan teknik memiliki persentase sebesar $20 \%$.

Hasil kemampuan berpikir kritis pada indikator 1 tentang memberikan penjelasan dasar memiliki persentase ketercapaian sebesar $31 \%$ termasuk dalam kategori sedang. Pada aspek ini soal yang pertama peneliti menganalisis kemampuan siswa dalam memberikan penjelasan dasar mengenai persamaan dan perbedaan pada dua buah fenomena. Soal yang diberikan siswa berupa perbandingan dua zat yaitu zat padat dan zat cair yang dipindahkan ke suatu tempat. Setelah itu siswa diminta apakah ada persamaan dan perbedaan dari volume dan bentuk kedua zat tersebut setelah dipindahkan. Siswa masih kurang dapat memberikan penjelasan dasar mengenai persamaan dan perbedaan yang diakibatkan oleh fenomena yang sama. Soal yang kedua pada aspek ini yaitu peneliti menganalisis alasan utama dari sebuah fenomena. Siswa disuruh menjelaskan alasan utama kenapa ketika dua buah balon dengan kondisi satu belum ditiup dan yang satu sudah ditiup digantungkan pada setiap ujung lidi sehingga menyebabkan kondisinya tidak seimbang. Siswa masih kurang dalam memberikan penjelasan dasar mengenai alasan utama yang menyebabkan suatu kejadian atau peristiwa. Pemahaman yang lebih dalam diperlukan mengenai konsep massa suatu zat dan memberikan berbagai macam contoh fenomena dalam satu konsep yang akan membuat siswa bisa membandingkan fenomena yang ada. Sebuah konsep mungkin sudah diketahui siswa. Namun, siswa belum tentu bisa menggunakannya untuk menjelaskan sebuah fenomena (Carson, 2007).

Kemampuan berpikir kritis pada indikator 2 tentang membangun keterampilan dasar merupakan indikator yang memiliki persentase ketercapaian tertinggi sebesar $61 \%$ dengan kategori tinggi. Pada aspek ini peneliti menganalisis kemampuan siswa dalam menggunakan prosedur yang ada. Soal yang pertama pada aspek ini siswa dilatih agar bisa menggunakan proses pemisahan campuran yang tepat. Fenomena yang tertulis dalam soal yaitu ketika sebuah larutan sirup yang terdiri dari gula, air, pewarna dan perasa. Kemudian, siswa diminta untuk menggunakan metode pemisahan campuran yang tepat ketika harus mendapatkan air murni dari larutan sirup tersebut. Soal yang kedua pada aspek ini siswa diminta untuk mengamati gambar purubahan wujud zat cair. Fenomena perubahan wujud zat cari yang terjadi yaitu bermula dari air yang berwujud padat berbentuk es batu kemudian dipanaskan dan berubah menjadi cair setelah itu dipanaskan hingga air berubah jadi uap. Siswa disuruh mencatat hal-hal yang diperlukan yang terjadi pada proses perubahan wujud tersebut. Hasil 
jawaban siswa rata-rata sudah menunjukan jawaban yang sesuai dengan fenomena yang diamati. Meskipun sudah masuk kategori tinggi masih perlunya peningkatan kemampuan siswa membangun keterampilan dasar dalam meng-gunakan prosedur yang ada dan memperhatikan hasil observasi dengan melihat hal-hal yang sangat diperlukan. Kegiatan observasi dalam pembelajaran IPA yang melibatkan eksperimen melalui model pembelajaran berbasis inkuiri dapat meningkatkan kemampuan berpikir kritis (Arsal, 2017).

Kemampuan berpikir kritis pada indikator 3 tentang menyimpulkan memiliki persentase ketercapaian sebesar $17 \%$ dengan kategori sangat rendah. Soal pertama pada aspek ini peneliti menganalisis kemampuan siswa dalam hal berhipotesis. Fenomena yang tertulis dalam soal yaitu sebuah paku dimasukan ke dalam berbagai tabung yang berisi air, minyak dan ada yang tabung kosong. Kemudian siswa disuruh berhipotesis paku yang ditempat manakah yang akan berkarat. Soal yang kedua pada aspek ini yaitu disajikan narasi dua buah percobaan dua buah campuran dalam tabung. Selanjutnya disajikan ciri-ciri hasil dari percobaan tersebut. Siswa kemudian disuruh untuk menyimpulkan campuran tersebut homogen atau heterogen. Kemampuan siswa dalam menyimpulkan dari suatu percobaan atau gejala fenomena masih sangat kurang. Hal ini bisa disebabkan oleh proses pembelajaran yang terjadi kurang melibatkan siswa pada saat menyimpulkan atau membuat generalisasi. Kemampuan menyimpulkan dapat dilatih dengan cara menerapkan konsep, prinsip dan keterampilan yang telah mereka pelajari untuk memecahkan masalah yang mereka hadapi atau menyimpulkannya (Fakhriyah, 2014).

Kemampuan berpikir kritis pada indikator 4 tentang memberikan penjelasan lebih lanjut memiliki persentase ketercapaian sebesar $46 \%$ tergolong kategori sedang. Soal pertama pada aspek ini siswa disuruh memberikan penjelasan lebih lanjut dari sebuah deskripsi tentang unsur kimia yang saling bereaksi. Ketika Natrium merupakan logam yang mudah meledak dan Klorin adalah gas beracun. Namun, ketika keduanya bereaksi akan menjadi garam dapur yang dapat digunakan untuk memasak. Siswa diminta untuk memberikan penjelasan lebih lanjut tentang karakteristik dari garam dapur tersebut. Pada soal kedua aspek ini peneliti menganalisis jawaban siswa mengenai penjelasan lebih lanjut tentang konsep massa jenis. Pada soal disajikan beberapa gambar sendok dengan ukuran dan bentuk yang berbeda. Kemudian siswa memilih argumen yang benar berdasarkan konsep massa jenis. Konsep yang sesuai yaitu bahwa massa jenis benda tergantung dari jenis bahan, bukan tergantung dari volume dan massanya.
Kemampuan siswa dalam hal mendefinisikan istilah dan mempertimbangkan definisi masih perlu ditingkatkan agar bisa memberikan penjelasan yang lebih rinci. Peningkatan literasi sains siswa dalam pembelajaran memungkinkan siswa untuk bisa lebih komunikatif dalam mendefinisikan istilah-istilah yang ada. Hal ini dapat dilakukan pembelajaran dengan strategi debat aktif yang dapat melatihkan keterampilan berpikir kritis siswa (Pramesswari, Widodo, \& Qosyim, 2009).

Kemampuan berpikir kritis pada indikator 5 tentang strategi dan teknik memiliki persentase ketercapaian 20\% dengan kategori sangat rendah. Pada aspek ini peneliti menganalisis kemampuan siswa dalam hal strategi memilih kriteria yang mungkin sebagai solusi permasalahan. Soal pertama pada aspek ini siswa diberi sebuah permasalahan. Siswa disuruh menjelaskan mengapa para petani sering menaburkan kapur dilahan pertaniannya. Soal kedua pada aspek ini peneliti menganalisis kemampuan siswa menggunakan strategi logika. Siswa diberi soal tentang perubahan wujud zat. Siswa secara logika disuruh menentukan perubahan wujud yang memerlukan kalor. Penguasaan konsep siswa masih rendah sehingga kemampuan siswa masih rendah dalam hal memutuskan suatu tindakan, memilih kriteria sebagai solusi permasalahan dan memberikan penjelasan berdasarkan logika. Kurangnya penguasaan konsep sehingga membuat siswa meresa ragu untuk memutuskan suatu tindakan. Kegiatan membaca kritis melalui berita tentang sains yang kemudian dianalisis akan membantu siswa menghubungkan berbagai konsep yang telah dipelajari di kelas dan mampu menerapkannya dalam kehidupan sehari-hari (Oliveras dkk, 2013).

Hasil analisis secara keseluruhan rata-rata kemampuan berpikir kritis siswa memiliki ketercapaian sebesar 35.2\% dengan kategori sedang. Hal ini sesuai dari penelitain lain yang menyebutkan bahwa keterampilan berpikir siswa SMP masih tergolong rendah (Saputra dkk, 2016; Hidayanti dkk, 2016; Rahmawati dkk, 2016). Kemampuan berpikir kritis siswa sangat dipengaruhi oleh kemampuan awal siswa pada pokok bahasan yang diujikan, sedangkan perbedaan jenis kelamin siswa tidak mempengaruhi keterampilan berpikir kritis (Hayudiyani, dkk. 2017). Berkaitan dengan aspek gender baik lakilaki maupun perempuan, pembelajaran sains/IPA ditujukan kepada seluruh siswa secara merata dan diharapkan mampu mengembangkan potensi sesuai dengan tahap perkembangan siswa (Ikhsanudin dkk, 2016).

Kemampuan berpikir kritis akan sulit dimiliki siswa apabila dalam proses pembelajaran tidak menerapkan model pembelajaran yang melatih kemampuan berpikir kritis. Proses pembelajaran sebaiknya tidak mementingkan hafalan karena tidak dapat meningkatkan kemampuan berpikir kritis (Snyder, dkk, 2008). Hasil dari TIMSS 2015 (Trend in International Mathematics and Science 
Study) menunjukan bahwa siswa Indonesia sudah menguasai soal yang bersifat rutin, pengetahuan dan fakta yang berkonteks keseharian. Namun, masih perlu peningkatan kemampuan berpikir tingkat tinggi seperti menarik kesimpulan, berpikir kritis, dan mengintegrasikan informasi. (PuspendikKemendikbud, 2016). Beberapa model dan pendekatan dalam pembelajaran dapat meningkatkan keterampilan berpikir kritis siswa. Penggunaan model pembelajaran siklus 7E dapat meningkatkan keterampilan berpikir kritis (Buntod dkk, 2010; Patmah dkk, 2017).

Implementasi pendekatan konflik kognitif pada pokok bahasan tekanan dapat meningkatkan kemampuan berpikir kritis siswa (Setyowati dkk, 2011). Selain itu, dalam rangka menghadapi era abad21 tentang peran teknologi dan informasi penggunaan multimedia dalam pembelajaran sangat diperlukan dalam mengembangkan keterampilan berpikir kritis. Penggunaan multimedia dalam pembelajaran seperti video real life atau multimedia berbasis kontekstual dapat mengkongkretkan permasalahan sehingga dapat meningkatkan keterampilan berpikir kritis (Basu, 2012; Putra dkk, 2015; Surachman dkk, 2015).

\section{Kesimpulan}

Hasil penelitian menunjukan kemampuan berpikir kritis siswa pokok bahasan klasifikasi materi dan perubahannya memiliki ketercapaian 35.2\% dengan kategori rendah. Analisis kemampuan berpikir kritis setiap indiktor menunjukan ketercapaian yang bervariasi. Indikator memberikan penjelasan dasar memiliki ketercapaian sebesar $31 \%$ dengan kategori rendah, indikator membangun keterampilan dasar memiliki ketercapaian sebesar $61 \%$ dengan kategori tinggi, indikator menyimpulkan memiliki ketercapaian sebesar $17 \%$ dengan kategori sangat rendah, indikator memberikan penjelasan lebih lanjut memiliki ketercapaian sebesar $46 \%$ dengan kategori sedang, serta indikator strategi dan teknik memiliki ketercapaian sebesar 20\% dengan kategori sangat rendah.

\section{Daftar Pustaka}

Arsal, Z. (2017). The Impact of Inquiry Based Learning on the Critical Thinking Dispositions of Pre-Service Science Teachers. International Journal of Science Education. 39(10): 1-13

Basu R. R., \& McMahon, G. T. (2012). Video-based cases disrupt deep critical thinking in problembased learning. Medical Education, 46(4), 426435 .
Buntod, P. C., Suksringam, P., \& Singseevo, A. (2010). Effects of Learning Environmental Education on Science Process Skills and Critical Thinking of Mathayomsuksa 3 Students with Different Learning Achievements. Journal of Social Sciences. 6(1): 60-63

Carson, J. (2007). A Problem with Problem Solving: Teaching Thinking without Teaching Knowledge. The Matematics Educator. 17(2): 714

Dicerbo, K. (2014). Assessment and teaching of 21st century skills. Assessment in Education: Principles, Policy \& Practice. 502-505.

Ennis, R.H. (2011). The Nature of Critical thinking: An Outline of Critical Thinking Dispositions and Abilities. University of Illinios. Diakses dari: https://education.illinois.edu/docs/defaultsource/faculty-documents/robertennis/thenatureofcriticalthinking_51711_000.pd f?sfvrsn=7bb51288_2

Fakhriyah, F. (2014). Penerapan Problem Based Learning Dalam Upaya Mengembangkan Kemampuan Berpikir Kritis Mahasiswa. Jurnal Pendidikan IPA Indonesia. 3 (1): 95-101

Gazali, Erfan. (2018). Pesantren Di Antara Generasi Alfa dan Tantangan Dunia Pendidikan Era Revolusi Industri 4.0. Jurnal Ilmiah Kajian Islam. 2 (2): 94-109.

Hartini \& Sukardjo. (2015). Pengembangan Higher Order Thinking Multiple Choice Test untuk Mengukur Keterampilan Berpikir Kritis IPA Kelas VII SMP/MTs. Jurnal Inovasi Pendidikan IPA. 1(1): 86-101

Hayudiyani, M., Arif, M., \& Risnasari, M. (2017). Identifikasi Kemampuan Berpikir Kritis Siswa Kelas X TKJ Ditinjau Dari Kemampuan Awal dan Jenis Kelamin Siswa Di SMKN 1 Kamal. Jurnal Ilmiah Edutic. 4(1): 21-27

Hidayanti, D., As'ari, A. R., Daniel, T. (2016). Analisis Kemampuan Berpikir Kritis Siswa Smp Kelas IX Pada Materi Kesebangunan. Prosiding Konferensi Nasional Penelitian Matematika dan Pembelajarannya (KNPMP I). ISSN: 2502-6526 Ikhsanudin, Subali, B., \& Hidayyati, S. (2016). Kemampuan Berpikir Divergen Keterampilan Proses Sains Aspek Biologi Siswa SD Berdasarkan Kegiatan Bimbingan Belajar. Jurnal Pendidikan Biologi. 5(1): 19-29.

Kalelioglu, F \& Gilbahar, Y. (2013). The Effect of Instructional Techniques on Critical Thinking and Critical Thinking. Education Technology \& Society: $17(1)$ : 248-258

Kleinig, J. (2018). Trust and critical thinking. Educational Philosophy and Theory, 50(2): 133-143 
Liberna, H. (2013). Peningkatan Kemampuan Berpikir Kritis Matematis Siswa Melalui Penggunaan Metode Improve pada Materi Sistem Persamaan Linear Dua Variabel. Jurnal Formatif. 2(3): 190-197.

Oliveras, B., Marquez, C., \& Sanmarti, N. (2013). The Use of Newspaper Articles as a Tool to Develop Critical Thinking in Science Classes. International Journal of Science Education. 3(6): 885-905

Patmah, Purwoko, A. A., \& Muntar. (2017). Pengaruh Model Pembelajaran Learning Cycle 7E Terhadap

Hasil

Belajar Kimia Ditinjau dari Kemampuan Berpikir Kritis Siswa. Jurnal Penelitian Pendidikan IPA (JPPIPA). 3(2): 69-86

Permendikbud nomor 22 Tahun 2006

Pramesswari, A. S., Widodo, W., \& Qosyim, A. (2009). Penerapan Strategi Debat Aktif untuk Melatihkan Ketrampilan Berpikir Kritis pada Materi Pemanasan Global. Jurnal Pendidikan Matematika. 4(3): 1-6.

Pusat Penilaian Pendidikan. 2016. Hasil TIMSS 2015. Badan Penelitian dan Pengembangan Kemendikbud. Diakeses dari https://puspendik.kemdikbud.go.id/seminar/uplo ad/Hasil\%20Seminar\%20Puspendik\%202016/TI MSS\%20infographic.pdf

Putra, Pramudya Dwi Aristya, Sudarti, S. (2015). Real life video evaluation with e-learning system to improve critical thinking skills student. Jurnal Kependidikan, 45(1), 67-89.

Rahmawati, I., Hidayat, A., Rahayu, S. (2016). Analisis Keterampilan Berpikir Kritis Siswa SMP Pada Materi Gaya dan Penerapannya. Prosiding Semnas Pendidikan IPA Pascasarjana UM. 1: 1112-1119.

Santos. L. F. (2017). The Role of Critical Thinking in Science Education. Journal of Education and Practice. 8(20): 159-173

Saputra, H,. Hidayat, A, \& Munzil. (2016). Profil Kemampuan Berpikir Kritis Siswa SMP N 7 Pasuruan. Proseding Semnas Pendidikan IPA Pascasarjana UM. 1: 943-949

Setyowati, A. Subali, B. \& Mosik. (2011). Implementasi Pendekatan Konflik Kognitif Dalam Pembelajaran Fisika Untuk Menumbuhkan Kemampuan Berpikir Kritis Siswa SMP Kelas VIII. Jurnal Pendidikan Fisika Indonesia. 7: 89-96

Snyder, L.G., \& Snyder, M.J. (2008). Teaching Critical Thinking and Problem Solving Skill. Delta Pi Epsilon Journal. 50(2): 90-99.

Sudarisman, S. (2015). Memahami hakikat dan karakteristik pembelajaran biologi dalam upaya menjawab tantangan abad 21 serta optimalisasi implementasi kurikulum 2013. Jurnal Florea, 2(1): 29-35.

Surachman, M., Muntari, \& Savalas, L. R. T. (2015). Pengembangan Multimedia Interaktif Berbasis Kontekstual untuk Meningkatkan Keterampilan Berpikir Kritis Siswa Kelas XI Pada Materi Pokok Sistem Koloid. Jurnal Penelitian Pendidikan IPA (JPPIPA). 1(1): 24-34

Syamsuar \& Reflianto. (2018). Pendidikan dan Tantangan Pembelajaran Berbasis Teknologi Informasi di Era Revolusi Industri 4.0. Jurnal Ilmiah Teknologi Pendidikan. 2(2).

Tresnawati, Hidayat, W., \& Rohaeti, E. (2017). Kemampuan Berpikir Kritis Matematis dan Kepercayaan Diri Siswa SMA. Symmetry Pasundan Journal of Research in Mathematics Learning and Education, 2(2): 116-122.

Wijaya, E. Y., Sudjimat, D. A., \& Nyoto, A. (2016). Transformasi Pendidikan Abad 21 Sebagai Tuntutan Transformasi Pendidikan Abad 21 Sebagai Tuntutan. Prosiding Seminar Nasional Pendidikan Matematika 2016. 1: 263-278. 